\title{
Genera-Specific Immunofluorescence Labeling of Ammonia Oxidizers with Polyclonal Antibodies Recognizing Both Subunits of the Ammonia Monooxygenase
}

\author{
C. Fiencke and E. Bock \\ Institut für Allgemeine Botanik, Universität Hamburg, D-22609 Hamburg, Germany \\ Received: 15 November 2002 / Accepted: 20 March 2003 / Online publication: 4 March 2004
}

\section{Abstract}

Polyclonal antibodies that recognize the two subunits $A m o A$ and $A m o B$ of the ammonia monooxygenase (AMO) were applied to identify ammonia-oxidizing bacteria by immunofluorescence (IF) labeling in pure, mixed, and enriched cultures. The antibodies against the AmoA were produced using a synthetic peptide of the AmoA of Nitrosomonas eutropha, whereas the antibodies against the AmoB had been developed previously is against the whole B-subunit of the AMO [Pinck et al. (2001) Appl Environ Microbiol 67:118-124]. Using IF labeling, the AmoA antibodies were specific for the detection of all species of the genus Nitrosomonas. In contrast, the antiserum against AmoB labeled all genera of ammonia oxidizers of the $\beta$-subclass of Proteobacteria (Nitrosomonas, Nitrosospira, Nitrosolobus, and Nitrosovibrio). The fluorescence signals of the AmoA antibodies were spread all over the cells, whereas the signals of the AmoB antibodies were associated with the cytoplasmic membranes. The specificity of the reactions of the antisera with ammonia oxidizers were proven in pure and mixed cultures, and the characteristic IF labeling and the morphology of the cells enabled their identification at the genus level. The genus-specific IF labeling could be used to identify ammonia oxidizers enriched from various habitats. In enrichment cultures of natural sandstone, cells of the genera Nitrosomonas, Nitrosovibrio, and Nitrosospira were detected. Members of the genus $\mathrm{Ni-}$ trosovibrio and Nitrosolobus were most prominent in enriched garden soil samples, whereas members of the genus Nitrosomonas dominated in enriched activated sludge. The antibodies caused only slight background fluorescence on sandstone and soil particles compared to oligonucleotide probes, which could not be used to detect

Correspondence to: C. Fiencke; E-mail: Claudia@Fiencke.de ammonia oxidizers on these materials because of strong nonspecific fluorescence.

\section{Introduction}

Ammonia-oxidizing bacteria play an essential part in the cycling of reduced nitrogen compounds throughout marine, freshwater, and soil environments. Chemolithoautotrophic bacteria convert ammonia to nitrite by two key enzymes and assimilate $\mathrm{CO}_{2}$ as the major carbon source. The first enzyme, the membrane-bound ammonia monooxygenase (AMO) catalyzes the oxidation of ammonia to hydroxylamine $[22,59]$, which is then further oxidized to nitrite by hydroxylamine oxidoreductase (HAO) $[3,46]$. Two proteins were sequenced and described as possible subunits of the AMO, a $27 \mathrm{kDa}$ sized membrane-associated protein (AmoA) containing, most likely, the active site of the AMO $[23,24]$ and a protein of $41 \mathrm{kDa}(\mathrm{AmoB})[8,33]$.

All known ammonia oxidizers are members of two lineages within the $\beta$ - and $\gamma$-subclasses of Proteobacteria according to comparative $16 \mathrm{~S}$ rRNA sequence analysis [30]. The marine species of the genus Nitrosococcus cluster within the $\gamma$-subclass of Proteobacteria [58]. Members of the four other genera Nitrosomonas (including Nitrosococcus mobilis, which belongs phylogenetically to Nitrosomonas), Nitrosospira, Nitrosolobus, and Nitrosovibrio, form a monophyletic assemblage within the $\beta$-subclass of the Proteobacteria [57]. The ammonia oxidizers have been divided into separate genera based on phenotypic characteristics, in particular cell shape and the arrangement of intracytoplasmic membranes (ICMs) [29]. The coccoid cells of the marine Nitrosococcus species have a centrally located stack of flattened ICMs, whereas the coccoid and rod-shaped cells of Nitrosomonas possess paired membranes running along the periphery of the cells. The pleomorphic lobes of Nitrosolobus are divided 
into cell compartments by cytomembranes [54]. No ICMs are found in the spiral and slender curved rods of members of the genera Nitrosospira and Nitrosovibrio, respectively [18]. Irrespective of the gross morphological differences of the genera, it has been suggested [19] and subsequently questioned [47] that the genera Nitrosospira, Nitrosolobus, and Nitrosovibrio should be reclassified in the single genus Nitrosospira because of the high levels of homology in their $16 \mathrm{~S}$ rRNA.

The presence of certain species of ammonia oxidizers within any given environmental niche, e.g., wastewater treatment plant or agricultural soil, gives evidence of environmental conditions. However, the detection and identification of these bacteria is difficult because of their slow growth rate and aggregation to biofilms [28, 43]. Traditional counting methods like the most-probablenumber (MPN) technique [31] are time-consuming and often underestimate the numbers of ammonia oxidizers in the natural environment $[7,27]$. Antibodies or 16S rRNAtargeted oligonucleotide probes are used for in situ analyses in order to avoid the limitations of the MPN technique. In previous studies antibodies had been developed using whole cells of ammonia oxidizers that recognize epitopes of the cell wall $[6,36,41,42,48,52]$. These antibodies were applied in ecological studies to detect and count ammonia oxidizers in bacterial communities using fluorescence microscopy, and 10 to 1000 -fold greater cell numbers were found compared to MPN techniques [27, $48,51]$. However, this approach is not entirely cultureindependent because ecologically relevant strains have to be isolated prior to antibody development. As ammonia oxidizers show high serological diversity within even one genus $[6,52]$, unculturable bacteria are consequently not detectable using antibodies raised against whole cells, and a variety of antibodies are required. In contrast to antibodies to cell envelopes, antibodies to key enzymes of $\mathrm{N}$ cycling bacteria such as ammonia oxidizers [38], nitrite oxidizers $[1,4,5]$, and denitrifying bacteria $[10,11,26$, 53] could be successfully applied for the detection of these bacteria in culture-independent approaches.

In this study, polyclonal antibodies were produced against the AmoA subunit of the AMO. The specificity of AmoA antibodies was tested using immunoblotting of pure cultures of members of all genera of ammonia oxidizers, and immunofluorescence (IF) labeling with the AmoA antibodies and the previously described AmoB antibodies [38] was developed to visualize and identify ammonia oxidizers in pure, mixed, and enrichment cultures.

\section{Materials and Methods}

Bacterial Strains and Culture Conditions. All bacterial strains used in this study are listed in Table 1 . The 21 strains of ammonia oxidizers and 7 strains of nitrite oxidizers were derived from soil, sewage, a biowaste fermenter, cattle manure, a heating system, sandstone of historical buildings and sea water (for more details see [38]). All strains including the methane oxidizers Methylococcus capsulatus Bath, Methylomonas methanica Oo52006, and Methylocystis parvus 4a and the chemoorganotrophic bacteria Bacillus subtilis 019, Escherichia coli K12/067 (ATCC 23716), Methylobacterium radiotolerans, Paracoccus denitrificans 001 (ATCC 19367), and Pseudomonas sp. AM1 are stored in the culture collection of the Institut für Allgemeine Botanik, Abteilung Mikrobiologie, Universität Hamburg. All other strains were obtained from C. Coeur (University of Lyon I, Villeurbanne, France).

Terrestrial and freshwater ammonia oxidizers were grown at $28^{\circ} \mathrm{C}$ in mineral salts medium [28] in the presence of $10 \mathrm{mM}$ ammonium. Nitrosomonas cryotolerans $\mathrm{Nm}$ 55, Nitrosomonas halophila Nm 1, and Nitrosococcus mobilis Nc 2 were grown in the same medium containing $10 \mathrm{~g} \mathrm{NaCl} \mathrm{L}^{-1}$. Nitrosomonas marina $\mathrm{Nm} 22$, Nitrosococcus oceani Nc 1, and Nitrosococcus halophilus Nc 4 were cultivated in seawater medium of the following

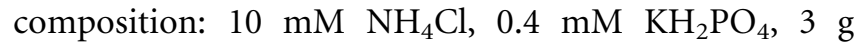
HEPES, and $1 \mathrm{~mL} 0.05 \%(\mathrm{w} / \mathrm{v})$ cresol red solution per liter of $40 \%$ seawater.

Nitrobacter hamburgensis $\mathrm{X}_{14}$, Nitrobacter winogradskyi Engel, and Nitrobacter vulgaris $\mathrm{K}_{48}$ were grown mixotrophically in the presence of $2 \mathrm{~g}$ of $\mathrm{NaNO}_{2} \mathrm{~L}^{-1}$ [9]. Nitrospira moscoviensis $\mathrm{M}-1$ was cultivated in mineral medium with $0.2 \mathrm{~g}$ of $\mathrm{NaNO}_{2} \mathrm{~L}^{-1}$ [13]. Nitrospina gracilis 3, Nitrospina sp. 347, and Nitrococcus mobilis 231 were cultivated in seawater media according to Watson and Waterbury [55]. The cultures were incubated at $28^{\circ} \mathrm{C}$ expect Nitrospira moscoviensis $\mathrm{M}-1$, which was incubated at $37^{\circ} \mathrm{C}$.

The methane oxidizers were cultivated in nitrate mineral salts medium [56] containing $0.25 \mu \mathrm{M} \mathrm{CuSO}_{4}$ with a $3 \%$ methane synthetic air atmosphere. The methylotrophs were grown in mineral medium with $0.15 \%(\mathrm{w} / \mathrm{v})$ methanol [15]. All other bacterial strains were cultivated according to the instructions of the American Type Culture Collection (ATCC).

Enrichment Cultures. For the enrichment of ammonia oxidizers, activated sludge, ground natural sandstone, and garden soil were added to mineral salts medium [28] containing $10 \mathrm{mM}$ ammonium and incubated for 2 weeks at $28^{\circ} \mathrm{C}$. The activated sludge samples originated from the aeration stage of the sewage treatment plant in Dradenau near Hamburg, Germany, and had a $\mathrm{pH}$ of 8.0. Garden soil samples with a $\mathrm{pH}$ of 7.6 were obtained from the new botanical garden in Hamburg, Germany. Stone samples were taken from specially cut specimens $(5 \times 5 \times 1 \mathrm{~cm})$ from Baumberger sandstone, which had been exposed for 5 years in the new 
Table 1. Reactivity of AmoA- and AmoB-antibodies and 16S rRNA probes with ammonia oxidizers, methane oxidizers, nitrite oxidizers and different chemoorganotrophic bacteria by using immunoblot, immunofluorescence, and FISH techniques

\begin{tabular}{|c|c|c|c|c|c|c|c|c|c|}
\hline \multirow[b]{2}{*}{ Species } & \multirow[b]{2}{*}{ Strain } & \multicolumn{2}{|c|}{ Immunoblot } & \multicolumn{2}{|c|}{ IF labeling } & \multicolumn{4}{|c|}{ FISH } \\
\hline & & $A m o A-A b s$ & $A m o B-A b s$ & $A m o A-A b s$ & $A m o B-A b s$ & EUB 338 & Nso 190 & $N E U$ & Nsv 443 \\
\hline \multicolumn{10}{|c|}{ Ammonia oxidizers of the $\beta$-subclass of Proteobacteria } \\
\hline Nitrosomonas communis & $\mathrm{Nm} 2$ & - & + & + & + & + & $-[40]$ & $-[40]$ & $-[40]$ \\
\hline Nitrosomonas cryotolerans & Nm 55 & - & + & $+/-$ & + & + & $+[40]$ & $-[40]$ & $-[40]$ \\
\hline Nitrosomonas europaea & Freitag & + & + & + & + & + & + & + & - \\
\hline Nitrosomonas eutropha & N904 & + & + & + & + & + & + & + & - \\
\hline Nitrosomonas eutropha & Dave & + & + & + & + & + & n.t. & n.t. & n.t. \\
\hline Nitrosomonas halophila & $\mathrm{Nm} 1$ & + & + & + & + & + & $+[40]$ & $+[40]$ & $-[40]$ \\
\hline Nitrosomonas marina & Nm 22 & - & + & $+/-$ & + & + & $+[40]$ & $-[40]$ & $-[40]$ \\
\hline Nitrosomonas nitrosa & Nm 90 & - & + & + & + & + & $-[40]$ & $-[40]$ & $-[40]$ \\
\hline Nitrosomonas oligotropha & $\mathrm{Nm} 45$ & - & + & + & + & + & $-[40]$ & $-[40]$ & $-[40]$ \\
\hline Nitrosomonas sp. & Nm R1.24 & - & + & + & + & + & - & - & - \\
\hline Nitrosomonas ureae & $\mathrm{Nm} 10$ & - & + & + & + & + & $-[40]$ & $-[40]$ & $-[40]$ \\
\hline Nitrosococcus mobilis & Nc 2 & - & + & - & + & + & $-[40]$ & $-[40]$ & $-[40]$ \\
\hline Nitrosospira sp. & Nsp 1 & - & + & - & + & + & + & - & + \\
\hline Nitrosospira sp. & Nsp G1.6 & - & + & - & + & + & + & - & - \\
\hline Nitrosospira sp. & Nsp M1.3 & - & + & - & + & + & + & - & - \\
\hline Nitrosospira sp. & Nsp R6.2 & - & + & - & + & + & + & - & - \\
\hline Nitrosovibrio sp. & Nv G1.3 & - & + & - & + & + & n.t. & n.t. & n.t. \\
\hline Nitrosovibrio sp. & Nv K7.1 & - & + & - & + & + & n.t. & n.t. & \\
\hline Nitrosolobus multiformis & Nl 13 & - & + & - & & + & $+[40]$ & $-[40]$ & $+[40]$ \\
\hline \multicolumn{10}{|c|}{ Ammonia oxidizers of the $\gamma$-subclass of Proteobacteria } \\
\hline Nitrosococcus halophilus & Nc 4 & - & - & - & $+/-$ & n.t. & n.t. & n.t. & n.t. \\
\hline \multicolumn{10}{|c|}{ Methane oxidizers } \\
\hline Methylococcus capsulatus & Bath & - & - & - & $+/-$ & n.t. & n.t. & n.t. & n.t. \\
\hline Methylomonas methanica & Oo52006 & - & - & - & - & n.t. & n.t. & n.t. & n.t. \\
\hline Methylocystis parvus & $4 \mathrm{a}$ & - & - & - & - & n.t. & n.t. & n.t. & n.t. \\
\hline \multicolumn{10}{|c|}{ Nitrite oxidizers } \\
\hline Nitrobacter hamburgensis & $\mathrm{X}_{14}$ & - & - & - & - & n.t. & n.t. & n.t. & n.t. \\
\hline Nitrobacter vulgaris & $\mathrm{K}_{48}$ & - & - & - & - & n.t. & n.t. & n.t. & n.t. \\
\hline Nitrobacter winogradskyi & Engel & - & - & - & - & n.t. & n.t. & n.t. & n.t. \\
\hline Nitrospina gracilis & 3 & - & - & - & - & n.t. & n.t. & n.t. & n.t. \\
\hline Nitrospina sp. & 347 & - & - & - & - & n.t. & n.t. & n.t. & n.t. \\
\hline Nitrospira moscoviensis & M-1 & - & - & - & - & n.t. & n.t. & n.t. & n.t. \\
\hline Nitrococcus mobilis & 231 & - & - & - & - & n.t. & n.t. & n.t. & n.t. \\
\hline \multicolumn{10}{|c|}{ Chemoorganotrophic bacteria } \\
\hline Agrobacterium tumefaciens & GM 19023 & - & - & n.t. & n.t. & n.t. & n.t. & n.t. & n.t. \\
\hline Alcaligenes faecalis & ATCC 8750 & - & - & n.t. & n.t. & n.t. & n.t. & n.t. & n.t. \\
\hline Azorhizobium sp. & 24 & - & - & n.t. & n.t. & n.t. & n.t. & n.t. & n.t. \\
\hline Azospirillum lipoferum & ATCC 29707 & - & - & n.t. & n.t. & n.t. & n.t. & n.t. & n.t. \\
\hline Bacillus azotoformans & ATCC 29788 & - & - & n.t. & n.t. & n.t. & n.t. & n.t. & n.t. \\
\hline Bacillus subtilis & 019 & - & - & - & - & n.t. & n.t. & n.t. & n.t. \\
\hline Escherichia coli & ATC 23716 & - & - & - & - & n.t. & n.t. & n.t. & n.t. \\
\hline Methylobacterium radiotolerans & ATC 19367 & - & - & - & - & n.t. & n.t. & n.t. & n.t. \\
\hline Pseudomonas sp. & AK15 & - & - & n.t. & n.t. & n.t. & n.t. & n.t. & n.t. \\
\hline Pseudomonas sp. & AM1 & - & - & - & - & n.t. & n.t. & n.t. & n.t. \\
\hline
\end{tabular}

$+=$ bright reaction, $+/-=$ slight reaction, $-=$ no reaction.

Abs: antibodies; n.t.: not determined.

[40] results of Purknold et al. (2000).

botanical garden of Hamburg, Germany. After this exposure, the sandstones were covered with green algae biofilms and other microorganisms and showed visible signs of weathering. The sandstone had a $\mathrm{pH}$ of 8.4 and was ground by pestle and mortar.
Development of Antibodies. A 15-residue synthetic peptide corresponding to the AmoA N-terminal peptide sequence of Nitrosomonas eutropha $\mathrm{Nm} 57$ was produced and conjugated to keyhole limpet hemocyanin (KHL)-protein (Biotrend, Cologne, Germany). The 
SwissProt accession numbers for N. eutropha Nm 57 amoA1 and $a m o A 2$ are U51630 and U72670, respectively. Antiserum against this synthetic peptide was raised in rabbits (Biotrend). AmoB-antibodies were recently produced by Pinck et al. [38] using the whole subunit of Nitrosomonas eutropha N904 for immunization of chickens.

Immunoblotting. Protein extracts of pure cultures (1.5 mg protein $\mathrm{mL}^{-1}$ ) were separated by SDS-PAGE, electroblotted onto a cellulose nitrate membrane using a discontinuous buffer system, and subsequently applied to the immunostaining. The $27-\mathrm{kDa}$ AmoA protein and the 41-kDa AmoB protein were detected in separate immunoblots. Alkaline phosphatase conjugated anti-rabbit antibodies (Sigma) and alkaline phosphatase conjugated anti-chicken antibodies (Sigma) were used as secondary antibodies for the detection of AmoA and AmoB antibodies, respectively. For the enzyme reaction $0.005 \%$ 5-bromo-4-chloro-3-indolyl phosphate and 0.001\% 4-nitro-blue-tetrazolium was employed. The detailed procedures of SDS-PAGE, electroblotting, and immunostaining were given by Pinck et al. [38].

IF Labeling. For IF labeling cells of pure and enrichment cultures were harvested by centrifugation and stored overnight in phosphate-buffered saline (PBS)ethanol (1:1) at $-20^{\circ} \mathrm{C}$. The samples were placed on slides and dehydrated by using 50, 80, and $96 \%$ ethanol ( $3 \mathrm{~min}$ each) [17]. The cells were then treated with lysozyme to enhance the permeation of the antibodies [16]. All samples were blocked with PBS containing 3\% bovine serum albumin (BSA) for $30 \mathrm{~min}$ at room temperature. The samples were then simultaneously incubated overnight with the AmoA- and AmoB-antibodies diluted 1:10 in PBS containing $0.05 \%$ BSA and $0.025 \%$ Tween 20. Afterward, the cells were incubated with secondary antibodies diluted 1:100 in PBS containing 0.05\% BSA and $0.025 \%$ Tween 20 for $1 \mathrm{~h}$ in the dark at room temperature. The secondary antibodies were Cy2-labeled antirabbit (Biotrend) and Cy3-labeled anti-chicken antibodies (Biotrend) for binding AmoA and AmoB antibodies, respectively. The reactions were stopped by washing the slides in PBS. Control preparations without primary antibodies were included in every experiment. Samples were stained with $4^{\prime}, 6$-diamidino-2-phenylindole (DAPI) $\left(10 \mu \mathrm{g} \mathrm{mL}^{-1}\right)$ for $5 \mathrm{~min}$ to detect total cells.

FISH. For fluorescence in situ hybridization (FISH) cells were fixed in 3\% formaldehyde for $1 \mathrm{~h}$ on ice and stored in PBS-ethanol $(1: 1)$ at $-20^{\circ} \mathrm{C}$. The samples were placed on slides and dehydrated by using 50,80 , and 96\% ethanol (3 min each) [17]. Afterward, they were incubated with the 16S rRNA directed oligonucleotide probe EUB338, Nso 190, NEU, or Nsv 443 in hybridi- zation buffer (0.9 M NaCl, $20 \mathrm{mM} \mathrm{M}$ Tris/HCl $\mathrm{pH}$ 7.2, $0.01 \%$ SDS) with a final concentration of $30 \%$ formamide (EUB338, Nsv 443) or $40 \%$ formamide (NEU, Nso 190) at a temperature of $46^{\circ} \mathrm{C}$ for $2 \mathrm{~h}$. As a competitor for $\mathrm{NEU}$, an equimolar amount of unlabeled oligonucleotide CTE was added. Probe EUB338 was used to detect members of the domain Bacteria [12], and probe Nso 190 detects all ammonia oxidizers of the $\beta$-subclass of Proteobacteria [35] except some Nitrosomonas strains (Table $1,[40])$. Probe NEU is specific for the detection of only a few members of the genus Nitrosomonas (Table 1 [40, 50]). Probe Nsv 443 is directed to Nitrosolobus multiformis, Nitrosospira briensis and Nitrosovibrio tenuis (Table $1[35,40]$ ). The probes were labeled with the fluorochrome Cy3 (MWG-Biotech AG). The samples were then incubated $20 \mathrm{~min}$ at $48^{\circ} \mathrm{C}$ in washing buffer (50 mM NaCl, $20 \mathrm{mM}$ Tris/ $\mathrm{HCl} \mathrm{pH} 7.2,0.01 \%$ SDS). Samples were stained with 4',6-diamidino-2-phenylindole (DAPI) $\left(10 \mu \mathrm{g} \mathrm{mL}^{-1}\right)$ for $5 \mathrm{~min}$ to detect total cells.

Fluorescence Microscopy and Confocal Laser Scanning Microscopy. DAPI stained cells were visualized by using Leica filter set A (BP 340-380 exc.; RKP 400; LP $425 \mathrm{em}$.$) . The Cy2 labeling of secondary AmoA anti-$ bodies and the Cy3 labeling of secondary AmoB antibodies and $16 \mathrm{~S}$ rRNA probes were visualized by using Leica filter set I 3 (BP 450-490 exc.; RKP 510; LP 515 em.) and Leica filter set N 2.1 (BP. 515-560 exc.; RKP 580; LP 590 em.), respectively.

IF labeling and FISH were additionally visualized with a confocal laser scanning microscope (CLSM) (model TCS 4D; Leica); excitation was supplied by an argon-krypton laser (488/568 exc.; LP 590, BP 520-560 em.). Image processing was performed with standard software (Scanware 5.1; Leica). No or only slight autofluorescence of biofilm, soil, or stone particles was found in the absence of fluorescent antibodies or probes.

Electron Microscopy. The methods used for cell fixation, embedding, ultrathin sectioning, and shadow casting were the methods described by Ehrich et al. [13]. Electron microscopy was performed with a Philips model 420 transmission electron microscope.

\section{Results}

Immunoblotting. Polyclonal antibodies were produced against a synthetic AmoA peptide, and their specificity was tested by immunoblotting of crude extracts. Various strains were investigated including 21 ammonia oxidizers, three methane oxidizers, seven nitrite oxidizers, and 14 strains of different chemoorganotrophic bacteria, which are all summarized in Table 1. In immunoblot studies the AmoA antibodies were highly specific for the detection of a $27-\mathrm{kDa}$ protein in cell extracts of Nitros- 


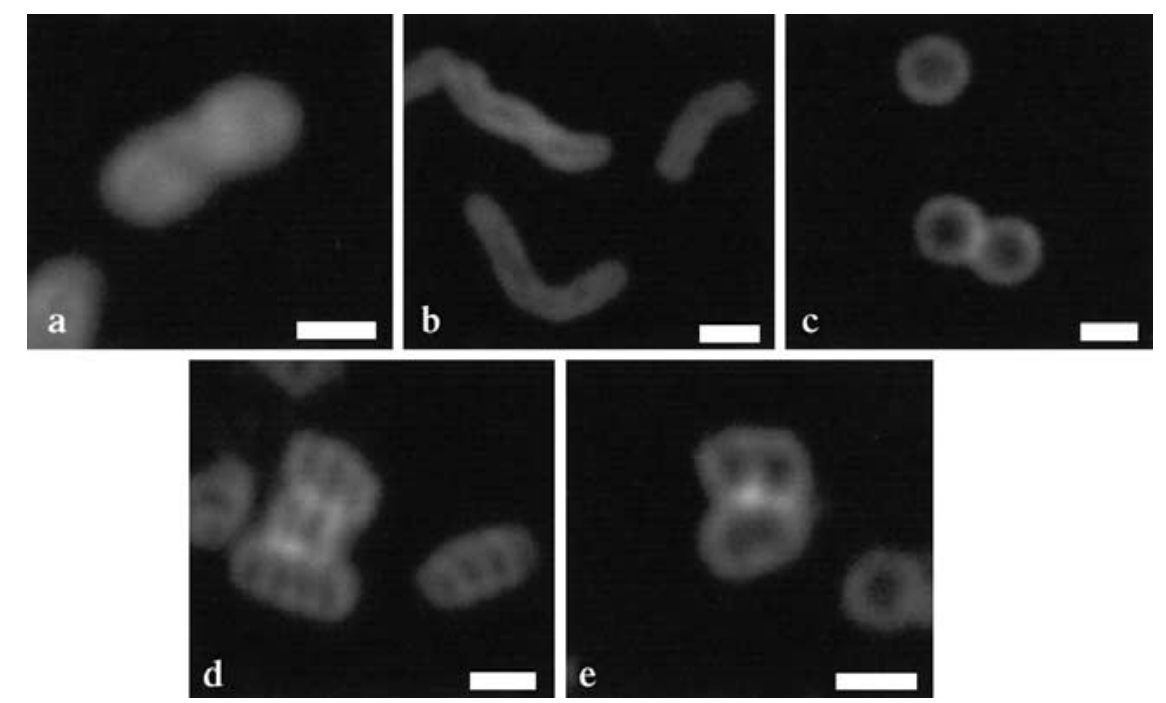

Figure 1. IF labeling with $A m o A$ and $A m o B$ antibodies of pure cultures of ammonia oxidizers belonging to the $\beta$-subclass of Proteobacteria (a) Nitrosomonas eutropha N904 (zoom step 16.4). (b) Nitrosovibrio sp. Nv K7.1 (zoom step 17.0). (c) Nitrosococcus mobilis Nc 2 (zoom step 15.8). (d) Four cells of Nitrosospira sp. Nsp R6.2 (zoomstep 20.0). (e) One single cell of Nitrosolobus multiformis $\mathrm{Nl} 13$ in the center (zoom step 23.0). Bars $=1 \mu \mathrm{m}$. The objective used was a Neoflutar objective (100x/1.4 oil). The images were obtained with a CLSM (model TCS 4D microscope; Leica) by using different zoom steps. Excitation of the green Cy2-labeled anti-rabbit antibodies for the detection of AmoA and red Cy3-labeled anti-chicken antibodies for the detection of AmoB was provided by an argon-krypton laser (488/568 exc./LP $590 \mathrm{em}$. and BP 520-560 em.).

omonas strains N. europaea Freitag, N. eutropha N904, N. eutropha Dave, and N. halophila Nm 1. Cells of all the other strains of Nitrosomonas sp. including Nitrosococcus mobilis Nc 2 could not be detected by the AmoA antibodies. These results are in contrast to those previously reported results that showed $A m o B$ antibodies detected the $41-\mathrm{kDa} A m o B$ of all ammonia oxidizers of the $\beta$ subclass of Proteobacteria [38]. These results are included in Table 1 for completeness. The AmoA-antibodies did not react with the crude extracts of the tested ammonia oxidizers of the $\gamma$-subclass of Proteobacteria, the methane oxidizers, the nitrite oxidizers, and the different chemoorganotrophic bacteria.

IF Labeling of Pure Cultures. Immunofluorescence (IF) labeling using the AmoA antibodies and the previously described AmoB antibodies [38] was developed on pure cultures to visualize intact cells of ammonia oxidizers. To obtain successful antibody penetration into the bacteria, the cells had to be stored in PBS-ethanol at $-20^{\circ} \mathrm{C}$ and were then treated with lysozyme. The AmoA antibodies detected all strains of the genus Nitrosomonas using IF labeling although fluorescence intensity varied (Table 1). Strains of Nitrosomonas sp. such as N. eutropha, N. europaea, and N. halophila that were successfully detected by immunoblotting were strongly stained, whereas cells of $N$. cryotolerans $\mathrm{Nm} 55$ and $N$. marina $\mathrm{Nm}$ 22 showed weak fluorescence. In contrast to the AmoA antibodies, the AmoB antibodies had a broad specificity, as they detected all strains of ammonia oxidizers of the
Proteobacteria that were tested (Table 1), all of which were stained strongly. Apart from weak IF labeling of Nitrosococcus halophilus Nc 1, Nitrosococcus oceani Nc 4, and Methylococcus methanica Oo52006 using the AmoBantibodies, both antisera did not react with ammonia oxidizers of the $\gamma$-subclass of Proteobacteria, methane oxidizers, nitrite oxidizers, and different chemoorganotrophic bacteria. In control experiments without AmoA and $A m o B$ antibodies the cells exhibited no fluorescence signals.

IF labeling revealed that the $A m o B$ antibodies were associated with the cytoplasmic membranes. As a result, the signals appeared at the cell periphery of cells of Nitrosomonas sp., Nitrosovibrio sp., and Nitrosococcus sp. (Fig. 1a-c). In cells of members of the genera Nitrosospira and Nitrosolobus, the fluorescence signals were also observed in the cytoplasm along the cytoplasmic membrane, which is vaulted to the center in tightly coiled cells of Nitrosospira sp. (Fig. 1d) and partially compartmentalizes the lobate cells of Nitrosolobus sp. (Fig. 1e).

Using both antibodies simultaneously, cells of Nitrosomonas sp. could be double-stained and showed bright red fluorescence of the secondary AmoB antibodies at the cell periphery as well as bright green signals of the secondary AmoA antibodies distributed over the whole cell (Fig. 1a). In contrast, cells of Nitrosococcus mobilis and cells belonging to the genera Nitrosovibrio, Nitrosospira, and Nitrosolobus were only labeled by the AmoB antibodies (Fig. 1b-e). The different IF labeling specificity of AmoA and AmoB antibodies together with the charac- 
teristic morphology of the cells enabled us to distinguish between the members of different genera of ammoniaoxidizers of $\beta$-Proteobacteria in pure cultures. Using IF labeling, the four new ammonia-oxidizing strains R1.24, G1.6, M1.3, and R6.2 isolated from historical building stones could be classified on the genus label. The straight rods of strain R1.24 were labeled with both antibodies (Table 1). In contrast the coiled rods of the strains G1.6, M1.3, and R6.2 could only detect by AmoB-antibodies (Table 1, Fig. 1d). Because of the specific IF labeling and typical morphology of the cells, strain R1.24 was classified as a member of the genus Nitrosomonas and the strains G1.6, Ml.3, and R6.2 were assigned to the genus Nitrosospira. This classification was underlined by electron microscopic investigations, where cells of strain R1.24 showed typical Nitrosomonas and cells of the strains G1.6, M1.3, and R6.2 typical Nitrosospira morphology (not shown).

In defined mixed cultures comprising members of the genus Nitrosomonas and Nitrosococcus mobilis or one strain of a Nitrosospira sp., a Nitrosovibrio sp., and a Nitrosolobus sp., respectively, cells could also be identified to the genus level by IF labeling (Fig. 2).

FISH of Pure Cultures. Using FISH, the 16S rRNA probe EUB338 detected all pure cultures of ammonia oxidizers that were tested (Table 1). Probes Nso 190, NEU, and Nsv 443 were only applied on pure cultures of Nitrosomonas europaea Freitag, Nitrosomonas eutropha N904, and Nitrosospira Nsp1 and the four isolated strains R1.24, G1.6, M1.3, R6.2 (Table 1). Probe Nso 190 labeled all the strains except strain R1.24. In contrast, probe NEU could only detect Nitrosomonas europaea Freitag and Nitrosomonas eutropha N904, and probe Nsv 443 detected Nitrosospira Nsp1, but none of the isolates (Table 1). For completeness, the specificity of probe Nso 190, NEU, and Nsv 443 for nearly all of the ammonia oxidizers used in this study was included in Table 1.

IF Labeling of Enrichment Cultures. Based on the results obtained from pure cultures, enrichment cultures either derived from activated sludge, natural sandstone or soil were analyzed using IF labeling and FISH.

In enrichment cultures from activated sludge from the sewage treatment plant in Dradenau, up to $90 \%$ of the free suspended cells and about $40 \%$ of biofilm-embedded cells could be labeled in situ by the antibodies. Almost all detected ammonia oxidizers could be identified as cells of the genus Nitrosomonas according to the specific IF labeling. Except for the cells associated with the biofilm, almost all ammonia oxidizers were labeled by AmoA and AmoB antibodies. The biofilm cells, however, were only detectable by AmoA-antibodies (Fig. 3b) because of nonspecific reactions of the AmoB antibodies with sludge particles (Fig. 3c), but could be identified as
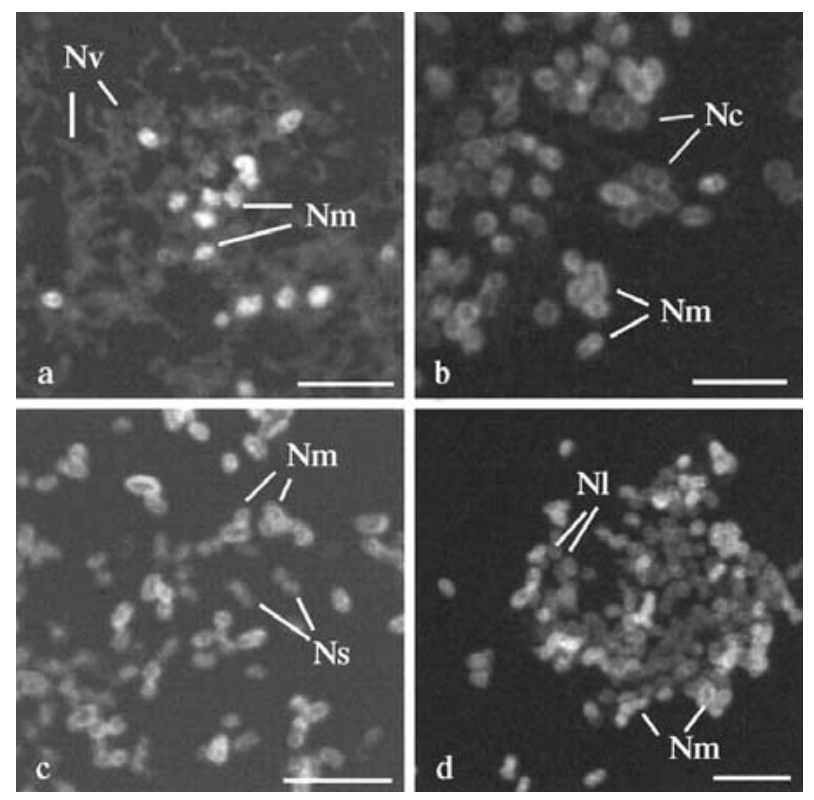

Figure 2. IF labeling with $A m o A$ and $A m o B$ antibodies of defined mixed cultures of Nitrosomonas eutropha N904 and (a) Nitrosovibrio sp. Nv K7.1 (zoom step 5.0), (b) Nitrosococcus mobilis Nc 2 (zoom step 6.2), (c) Nitrosospira sp. Nsp G1.6 (zoom step 5.4), (d) Nitrosolobus multiformis $\mathrm{Nl} 13$ (zoom step 3.8). Bars $=5 \mu \mathrm{m}$. The objective used was a Neoflutar objective $(100 \times / 1.4$ oil $)$. The images were obtained with a CLSM (model TCS 4D microscope; Leica) by using different zoom steps. Excitation of the green Cy2-labeled anti-rabbit antibodies for the detection of AmoA and red Cy3labeled anti-chicken antibodies for the detection of $\mathrm{AmoB}$ was provided by an argon-krypton laser (488/568 exc./LP $590 \mathrm{em}$. and BP 520-560 em.). Nc: Nitrosococcus; Nl: Nitrosolobus; Nm: Nitrosomonas; Ns: Nitrosospira.

Nitrosomonas sp. cells. Inside the biofilm, loosely aggregated single cells (Fig. 3d) and dense microcolonies (Fig. 3e) of Nitrosomonas sp. were found. Outside the biofilm only a few cells were exclusively stained with AmoB antibodies and could be identified as cells of Nitrosospira sp. and Nitrosococcus sp.. The IF labeling results were confirmed by FISH. Almost all DAPI-stained cells could be detected by probe EUB338. Outside the biofilm about $90 \%$ of the cells and about $40 \%$ of the cells inside the biofilm were stained with the Nitrosomonas sp. specific oligonucleotide probe Nso 190 and NEU. Only a few cells could be labeled by the Nitrosopira sp., Nitrosolobus sp., and Nitrosovibrio sp. specific probe Nsv 443.

In enrichment cultures prepared from samples of Baumberger sandstone, cells were mostly bound to particles and appeared mainly as single cells. About $68 \%$ of the cells were identified by IF labeling with AmoA and AmoB antibodies as cells of Nitrosomonas. About 17\% of the cells were only stained by AmoB antibodies and had typical Nitrosospira sp. and Nitrosovibrio sp. morphologies (Fig. 4a). In contrast to the IF labeling, the detection of cells with probes EUB338, Nso 190, NEU, and Nsv 443 


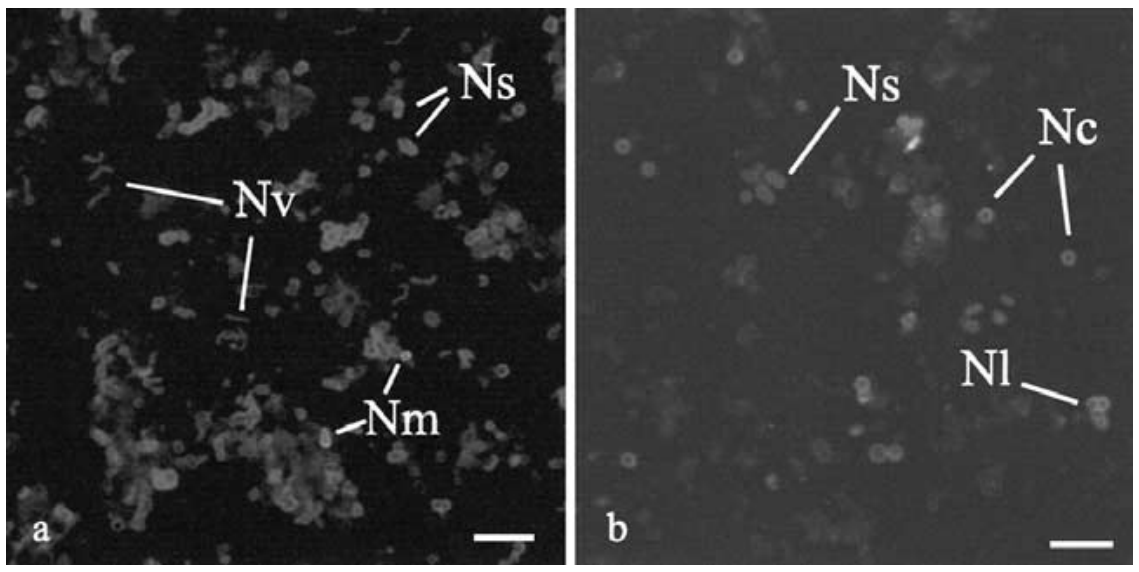

Figure 4. IF labeling with AmoA and AmoB antibodies of enrichment cultures from (a) Baumberger sandstone (zoom step 1.9), (b) garden soil samples (zoom step 2.3). Bars $=5 \mu \mathrm{m}$. The objective used was a Neoflutar objective $(100 \times / 1.4$ oil). The images were obtained with a CLSM (model TCS 4D microscope; Leica) by using different zoom steps. Excitation of the green Cy2-labeled anti-rabbit antibodies for the detection of AmoA and red Cy3-labeled anti-chicken antibodies for the detection of AmoB was provided by an argon-krypton laser (488/568 exc./LP 590 em. and BP 520-560 em.). Nc: Nitrosococcus; Nl: Nitrosolobus; Nm: Nitrosomonas; Ns: Nitrosospira; Nv: Nitrosolobus.

might result from the differences between the N-terminal AmoA sequences, which could have caused the different binding efficiency of the antibodies. All Nitrosomonas strains showing high AmoA-sequence similarity to $N$. eutropha, such as $N$. europaea and $N$. halophila, were intensively stained, whereas strains with low AmoA-sequence similarity such as $N$. cryotolerans and $N$. marina were weakly stained $[37,40]$. Only Nitrosococcus mobilis, close relative of Nitrosomonas eutropha [39, 40], could not be detected by AmoA antibodies. The N-terminal AmoA sequence of $N$. eutropha is identical with the sequence of N. europaea [37]. Aside from the two Nitrosomonas species, only the sequence of the $\mathrm{N}$ terminus of AmoA of one strain of N. cryotolerans is known [37], whereas the $\mathrm{N}$-terminal AmoA sequences of the other species of Nitrosomonas are known only partially (Nitrosococcus mobilis, SwissProt accession number AF037108) or not at all. The N-terminal AmoA sequence of N. cryotolerans differs from the sequence of N. eutropha [37], which might be the reason for the weak IF labeling using AmoA-antibodies. Recently, Norton and co-workers [37] described the AmoA-sequence of two new isolated strains of Nitrosomonas with N-terminal AmoA sequences, which further deviate from the sequence of N. eutropha and therefore might not be detected by AmoA antibodies. Although the N-terminal AmoA sequences of strains of the genera Nitrosospira, Nitrosovibrio, and Nitrosolobus correspond with the described sequence of $N$. cryotolerans [37], they did not react with the AmoA antibodies. The third and fourth amino acids of their AmoA are deleted and the glutamic acid in position 7 is replaced by aspartic acid [37]. The reason for this disagreement might be that little strain-specific deviations between the N-terminal AmoA-sequence exist, as described for Nitrosolobus multiformis [37], and the N. cryotolerans strain we used might correspond more with $N$. eutropha than the used strains of Nitrosospira sp., Nitrosovibrio sp., and Nitrosolobus sp. The different specificity of AmoA antibodies will only be completely explained when the $\mathrm{N}$ terminus of the AmoA of the ammonia oxidizer strains that were used in this study has been sequenced. If instead of the $\mathrm{N}$ terminal sequence a more conserved internal or C-terminal region of AmoA had been chosen, these antibodies might be reacted with all ammonia oxidizers of the $\beta$ subclass of Proteobacteria. In Nitrosococcus oceani, a member of the $\gamma$-subclass of Proteobacteria, only three amino acids of the $15 \mathrm{~N}$-terminal AmoA sequence correspond with the AmoA of N. eutropha [2, 37], and therefore it did not react with the antibodies. Further, no reaction of AmoA antibodies was found with the closely related particulate methane monooxygenase (pMMO) of methane oxidizing bacteria, because the $\mathrm{N}$-terminal pMMO sequence of Methylococcus capsulatus is almost identical to the AmoA of Nitrosococcus oceani [2] and therefore clearly differs from the AmoA sequence of $N$. eutropha. The fluorescent signals of all cells correlated with the locations of the AMO in the cytoplasmic and intracytoplasmic membranes [23].

Using both antisera simultaneously, the different IF labeling specificity of AmoA and AmoB antibodies together with the characteristic morphology of the cells enabled us to distinguish between the members of different genera of ammonia oxidizers of $\beta$-Proteobacteria in pure cultures as well as in mixed cultures. They could be applied for classification of new isolates of ammonia oxidizers. By IF labeling the isolates could assigned to the genus Nitrosomonas or Nitrosospira. This clear classification was not possible by using the $16 \mathrm{~S}$ rRNA probes 
NEU, Nso 190, and Nsv 443. This might be due to the choice of the probes. Although probe Nso 190 detected many ammonia oxidizers of the $\beta$-subclass of Proteobacteria [35], some Nitrosomonas strains were not included [40], and probe NEU is only specific for the detection of a few members of the genus Nitrosomonas $[40,50]$. Therefore it is not remarkable that strain R1.24, which was classified by IF labeling to genus Nitrosomonas, could not be detected by probes Nso 190 and NEU. For a clear classification of the Nitrosomonas isolate the probe $\mathrm{Nm} 0$ should be used, which cover all strains of Nitrosomonas but might not detect the other four genera of ammonia oxidizers [39, 40]. In contrast, no $16 \mathrm{~S}$ rRNA probe is thus far known that exclusively detects the genus Nitrosospira [40]. Therefore no probe exists that enables the clear classification of the isolates G1.6, M1.3, and R6.2, which were assigned by IF labeling to genus Nitrosospira. Although probe Nsv 443 has a broader specificity, as it is designed for the detection of Nitrosolobus sp., Nitrosospira sp., and Nitrosovibrio sp. $[35,40]$, it could not detect the isolates. In contrast to the antibodies, thus far no set of $16 \mathrm{~S}$ rRNA probes is available for the classification of ammonia oxidizers to the five genera [40].

In addition, the specific immunoreactions were suitable for the identification of ammonia oxidizers enriched from different natural samples. In enrichment cultures of activated sludge from the sewage treatment plant in Dradenau, cells of Nitrosomonas sp. were mainly detected, which could be confirmed using FISH analysis with the Nitrosomonas- specific oligonucleotide probes NEU and Nsv 443. This finding is in agreement with previous in situ IF and FISH analysis, and Nitrosomonas sp. was mostly isolated from activated sludge samples $[30,35,48]$. In enrichment cultures derived from sandstone, members of the genus Nitrosomonas were also mainly found. However, additional cells were exclusively detected by the AmoB antibodies, and combined with the characteristic morphology the cells could be identified as members of the genera Nitrosovibrio and Nitrosospira. In previous studies Nitrosovibrio sp. and Nitrosospira sp. were predominantly isolated from sandstone samples [34, 43]. In enrichment cultures from neutral garden soil $(\mathrm{pH}$ 7.6) from the new botanical garden in Hamburg, members of the genera Nitrosospira and Nitrosolobus were the most abundant ammonia oxidizers. In these cultures, coccoid cells were also detected by AmoB antibodies that might have been small cells of Nitrosolobus sp. or might have belonged to members of the genus Nitrosococcus ( $\beta$ Proteobacteria). Electron microscopic investigations of the same cultures revealed characteristic cells with a morphology and ultrastructure of small Nitrosolobus sp. cells (Schnier, personal communication), which is in agreement with recent studies in which Nitrosolobus [32, 49] and Nitrosospira [6, 19, 21, 25] were the most abundant ammonia oxidizers in loamy and arable soils with neutral $\mathrm{pH}$.

In contrast to the AmoA antibodies and the oligonucleotide probes, the AmoB antibodies could not be applied to detect ammonia oxidizers within the biofilm of the activated sludge sample because of nonspecific reactions. However, only slight nonspecific reaction of the antibodies appeared in the presence of stone and soil particles, and the IF cell signals could be easily distinguished from the background, whereas with probes EUB338, Nso 190, NEU, and Nsv 443 the detection of ammonia oxidizers failed in these samples.

The antibodies against the AmoA and AmoB subunits of the AMO detected all ammonia oxidizers of the $\beta$-Proteobacteria that were tested and therefore have an advantage over previous antibody detection methods, which were limited in the application to specific serological groups $[6,52]$ as they recognize specific epitopes of the cell wall $[41,42,48]$. Presumably, the antibodies against the key enzyme, especially the AmoB antibodies, might be used for the detection of all ammonia oxidizers of the $\beta$-subclass of Proteobacteria even those that have not been described. Beside the enrichment cultures, the antibodies may be further used for the direct in situ detection of ammonia oxidizers in natural samples with a sufficient number of cells. The AmoB antibodies might provide the only tool for detecting all species of ammonia oxidizers of the $\beta$-subclass of Proteobacteria simultaneously and exclusively [40].

\section{Acknowledgments}

We thank H.-P. Koops for contributing pure cultures of ammonia oxidizers, S. Bartosch for technical assistance and comments on the manuscript, and E. Spieck for scientific discussions.

\section{References}

1. Aamand, J, Ahl, T, Spieck, E (1996) Monoclonal antibodies recognizing nitrite oxidoreductase of Nitrobacter hamburgensis, $N$. winogradskyi, and N. vulgaris. Appl Env Microbiol 62: 2352-2355

2. Alzerreca, JJ, Norton, JM, Klotz, MG (1999) The amo operon in marine, ammonia-oxidizing $\gamma$-proteobacteria. FEMS Microbiol Lett 180: 21-29

3. Arciero, DM, Hooper, AB (1993) Hydroxylamine oxidoreductase from Nitrosomonas europaea is a multimer of an octa-heme subunit. J Biol Chem 268: 14645-14654

4. Bartosch, S, Wolgast, I, Spieck, E, Bock, E (1999) Identification of nitrite-oxidizing bacteria with monoclonal antibodies recognizing the nitrite oxidoreductase. Appl Environ Microbiol 65: 4126-4133

5. Bartosch, S, Hartwig, C, Spieck, E, Bock, E (2002) Immunological detection of Nitrospira-like bacteria in various soils. Microbiol Ecol 43: $26-33$

6. Belser, LW, Schmidt, EL (1978) Serological diversity within a terrestrial ammonia-oxidizing population. Appl Environ Microbiol 36: 589-593 
7. Belser, LW (1979) Population ecology of nitrifying bacteria. Ann Rev Microbiol 16: 309-333

8. Bergmann, DJ, Hopper, AB (1994) Sequence of the gene, amo B, for the $43 \mathrm{kDa}$ polypeptide of ammonia monooxygenase of Nitrosomonas europaea. Biochim Biophys Res Commun 204: 759-762

9. Bock, E, Koops, H-P, Möller, UC, Rudert, M (1990) A new facultatively nitrite oxidizing bacterium, Nitrobacter vulgaris sp. nov. Arch Microbiol 153: 105-110

10. Bothe, H, Jost, G, Schloter, M, Ward, BB, Witzel, K-P (2000) Molecular analysis of ammonia oxidation and denitrification in natural environments. FEMS Microbiol Rev 24: 673-690

11. Coyne, MS, Arunakumari, A, Averill, BA, Tiedje, JM (1989) Immunological identification and distribution of dissimilatory heme cd1 and nonheme copper nitrite reductases in denitrifying bacteria. Appl Environ Microbiol 55: 2924-2931

12. Daims, H, Brühl, A, Amann, R, Schleifer, K-H, Wagner, M (1999) The domain-specific probe EUB338 is insufficient for the detection of all bacteria: development and evaluation of a more comprehensive probe set. Syst Appl Microbiol 22: 434-444

13. Ehrich, S, Behrens, D, Lebedeva, E, Ludwig, W, Bock, E (1995) A new obligately chemolithoautotrophic, nitrite-oxidizing bacterium, Nitrospira moscoviensis sp. nov. and its phylogenetic relationship. Arch Microbiol 164: 16-23

14. Ensign, SA, Hyman, MR, Arp, DJ (1993) In vitro activation of ammonia monooxygenase from Nitrosomonas by copper. J Bacteriol 175: 1971-1998

15. Green, PN, Bousfield, IJ, Hood, D (1988) Three new Methylobacterium species: $M$. rhodesianum sp. nov., M. zatmani sp. nov., $M$. fuyisawanease sp. nov. Int J Syst Bacteriol 38: 124-127

16. Hahn, D, Amann, R, Ludwig, W, Akkermans, AD, Schleifer, K-H (1992) Detection of micro-organisms in soil after in situ hybridisation with rRNA-targeted, fluorescently labelled oligonucleotides. J Gen Microbiol 138: 879-887

17. Hahn, D, Amann, R, Zeyer, J (1993) Detection of mRNA in Streptomyces cells by whole-cell hybridization with digoxigeninlabeled probes. Appl Environ Microbiol 59: 2753-2757

18. Harms, H, Koops, H-P, Wehrmann, H (1976) An ammonia-oxidizing bacterium, Nitrosovibrio tenuis nov. gen. nov. sp. Arch Microbiol 108: 105-111

19. Hastings, RC, Ceccherini, MT, Miclaus, N, Saunders, JR, Bazzicalupo, M, McCarthy, AJ (1997) Direct molecular biological analysis of ammonia oxidising bacteria populations in cultivated soil plots treated with swine manure. FEMS Microbiol Ecol 23: 45-54

20. Head, IM, Hiorns, WD, Embley, TM, McCarthy, AJ, Saunders, JR (1993) The phylogeny of autotrophic ammonia-oxidizing bacteria as determined by analysis of $16 \mathrm{~S}$ ribosomal RNA gene sequences. J Gen Microbiol 139: 1147-1153

21. Hiorns, WD, Hastings, RC, Head, IM, McCarthy, AJ, Saunders, JR, Pickup, RW, Hall, GH (1995) Amplification of 16S ribosomal RNA genes of autotrophic ammonia-oxidizing bacteria demonstrates the ubiquity of Nitrosospira in the environment. Microbiology 141: 2793-2800

22. Hollocher, TC, Tate, ME, Nicholas, DJD (1981) Oxidation of ammonia by Nitrosomonas europaea. Definitive ${ }^{18} \mathrm{O}$-tracer evidence that hydroxylamine formation involves a monooxygenase. J Biol Chem 256: 10834-10836

23. Hyman, MR, Wood, PM (1985) Suicidal inactivation and labelling of ammonia mono-oxygenase by acetylene. Biochem J 227: 719-725

24. Hyman, MR, Arp, DJ (1992) ${ }^{14} \mathrm{C}_{2} \mathrm{H}_{2}$-and ${ }^{14} \mathrm{CO}_{2}$-labelling studies of the de novo synthesis of polypeptides by Nitrosomonas europaea during recovery from acetylene and light inactivation of ammonia monooxygenase. J Biol Chem 267: 1534-1545

25. Jiang, QQ, Bakken, LR (1999) Comparison of Nitrosospira strains isolated from terrestrial environments. FEMS Microbiol Ecol 30: $171-186$
26. Körner, H, Frunzke, K, Döhler, K, Zumft, WG (1987) Immunochemical patterns of distribution of nitrous oxide reductase and nitrite reductase (cytochrome $c d_{1}$ ) among denitrifying pseudomonas. Arch Microbiol 148: 20-24

27. Konuma, S, Satoh, H, Mino, T, Matsu, T (2001) Comparison of enumeration methods of ammonia-oxidizing bacteria. Wat Sci Technol 43: 107-114

28. Koops, H-P, Böttcher, B, Möller, UC, Pommerening-Röser, A, Stehr, G (1991) Classification of eight new species of ammoniaoxidizing bacteria: Nitrosomonas communis sp. nov., Nitrosomonas ureae sp. nov., Nitrosomonas aestuarii sp. nov., Nitrosomonas marina sp. nov., Nitrosomonas nitrosa sp. nov. Nitrosomonas eutropha sp. nov., Nitrosomonas oligotropha sp. nov. and Nitrosomonas halophila sp. nov. J Gen Microbiol 137: 1689-1699

29. Koops, H-P, Möller, UC (1992) The lithotrophic ammonia-oxidizing bacteria. In: Balows, A, Trüper, HG, Dworkin, M, Harder, W, Schleifer, KH (Eds.) The Prokaryotes, vol 3. Springer Verlag, New York, pp 2625-2637

30. Koops, H-P, Pommerening-Röser, A (2001) Distribution and ecophysiology of nitrifying bacteria emphasizing cultured species. FEMS Microbiol Ecol 1255: 1-9

31. Matulevich, VA, Strom, PF, Finstein, MS (1975) Length of incubation for enumerating nitrifying bacteria present in various environments. Appl Microbiol 29: 265-268

32. McDonald, RM (1986) Nitrification in soil: an introductory history. In: Prosser, JI (Ed.) Nitrification. IRL Press, Oxford, pp 116

33. McTavish, H, Fuchs, JA, Hooper, AB (1993) Sequence of the gene coding for ammonia-monooxygenase in Nitrosomonas europaea. J Bacteriol 175: 2436-2444

34. Meincke, M, Krieg, E, Bock, E (1989) Nitrosovibrio spp., the dominant ammonia oxidizing bacteria in building stones. Appl Environ Microbiol 55: 2108-2110

35. Mobarry, BK, Wagner, M, Urbain, V, Rittmann, BE, Stahl, DA (1996) Phylogenetic probes for analyzing abundance and spatial organization of nitrifying bacteria. Appl Environ Microbiol 62: 2156-2162

36. Noda, N, Ikuta, H, Ebie, Y, Hirata, A, Tsuneda, S, Matsumura, M, Sumino, T, Inamori, Y (2000) Rapid quantification and in situ detection of nitrifying bacteria in biofilms by monoclonal antibody method. Wat Sci Technol 41: 301-308

37. Norton, J, Alzerreca, JJ, Suwa, Y, Klotz, MG (2002) Diversity of ammonia monooxygenase operon in autotrophic ammonia-oxidizing bacteria. Arch Microbiol 177: 139-149

38. Pinck, C, Coeur, C, Potier, P, Bock, E (2001) Polyclonal antibodies recognizing the $A m o B$ protein of ammonia oxidizers of the $\beta$ subclass of the class Proteobacteria. Appl Environ Microbiol 67: 118-124

39. Pommerening-Röser, A, Rath, G, Koops, H-P (1996) Phylogenetic diversity within the genus Nitrosomonas. Syst Appl Microbiol 19: 344-351

40. Purkhold, U, Pommerening-Röser, A, Juretschko, S, Schmid, MC, Koops, H-P, Wagner, M (2000) Phylogeny of all recognized species of ammonia oxidizers based on comparative $16 \mathrm{~S}$ rRNA and amoA sequence analysis: implications for molecular diversity surveys. Appl Environ Microbiol 66: 5368-5382

41. Sanden, B, Grunditz, C, Hansson, Y, Dalhammar, G (1994) Quantification and characterisation of Nitrosomonas and Nitrobacter using monoclonal antibodies. Wat Sci Technol 29: 1-6

42. Smorczewski, WT, Schmidt, EL (1991) Numbers, activities, and diversity of autotrophic ammonia-oxidizing bacteria in a freshwater, eutrophic lake sediment. Can J Microbiol 37: 828-833

43. Spieck, E, Meincke, M, Bock, E (1992) Taxonomic diversity of Nitrosovibrio strains isolated from building sandstones. FEMS Microbiol Ecol 102: 21-26 
44. Suzuki, I, Kwok, S-C (1970) Cell-free ammonia oxidation by Nitrosomonas europaea extracts: effects of polyamines, $\mathrm{Mg}^{2+}$ and albumin. Biochem Biophys Res Commun 39: 950-955

45. Suzuki, I, Kwok, S-C, Dular, U, Tsang, DCY (1981) Cell-free ammonia-oxidizing system of Nitrosomonas europaea: general conditions and properties. Can J Biochem 59: 477-483

46. Terry, KR, Hooper, AB (1981) Hydroxylamine oxidoreductase: a 20-heme, 200000 molecular weight cytochrome $c$ with unusual denaturation properties which forms a 63000 molecular weight monomer after heme removal. Biochemistry 20: 7026-7032

47. Teske, A, Alm, E, Regan, JM, Toze, S, Rittmann, BE, Stahl, DA (1994) Evolutionary relationship among ammonia- and nitriteoxidizing bacteria. J Bacteriol 176: 6623-6630

48. Völsch, A, Nader, WF, Geiss, HK, Nebe, G, Birr, C (1990) Detection and analysis of two serotypes of ammonia-oxidizing bacteria in sewage plants by flow cytometry. Appl Environ Microbiol 140: $153-158$

49. Walker, $N$ (1978) On the diversity of nitrifiers in nature. In: Schlessinger, D (Ed.) Microbiology, Am Soc Microbol, Washington, DC, pp 346-347

50. Wagner, M, Rath, G, Amann, R, Koops, H-P, Schleifer, KH (1995) In situ identification of ammonia-oxidizing bacteria. Syst Appl Microbiol 18: 251-264

51. Ward, BB (1982) Oceanic distribution of ammonium oxidizing bacteria determined by immunofluorescent assay. J Mar Res 40: 1155-1172
52. Ward, BB, Carlucci, AF (1985) Marine ammonia- and nitrite-oxidizing bacteria: serological diversity determined by immunofluorescence in sewage plants by flow cytometry. Appl Environ Microbiol 56: 2430-2435

53. Ward, BB, Cockcroft, AR, Kilpatrick, KA (1993) Antibody and DNA probes for detection of nitrite reductase in seawater. J Gen Microbiol 139: 2285-2293

54. Watson, SW, Graham, LB, Remsen, CC, Valois, FW (1971) A lobular, ammonia-oxidizing bacterium. Nitrosolobus multiformis nov. gen. nov. sp. Arch Microbiol 76: 183-203

55. Watson, SW, Waterbury, JB (1971) Characteristics of two marine nitrite oxidizing bacteria, Nitrospina gracilis nov. gen. nov. sp. and Nitrococcus mobilis nov. gen. nov. sp. Arch Microbiol 77: 203-230

56. Whittenbury, R, Phillips, KC, Wilkinson, JF (1970) Enrichment, isolation and some properties of methane-utilizing bacteria. J Gen Microbiol 61: 205-218

57. Woese, CR, Weisburg, WG, Paster, BJ, Hahn, CM, Tanner, RS, Krieg, NR, Koops, H-P, Harms, H, Stackebrandt, E (1984) The phylogeny of purple bacteria: the beta subdivision. Syst Appl Microbiol 5: 327-336

58. Woese, CR, Weisburg, WG, Hahn, CM, Paster, BJ, Zablen, LB, Lewis, BJ, Macke, TJ, Ludwig, W, Stackebrandt, E (1985) The phylogeny of purple bacteria: the gamma subdivision. Syst Appl Microbiol 6: 25-33

59. Wood, PM (1986) Nitrification as a bacterial energy source. In: Prosser, JI (Ed.) Nitrification. IRL Press, Oxford, pp 39-62 